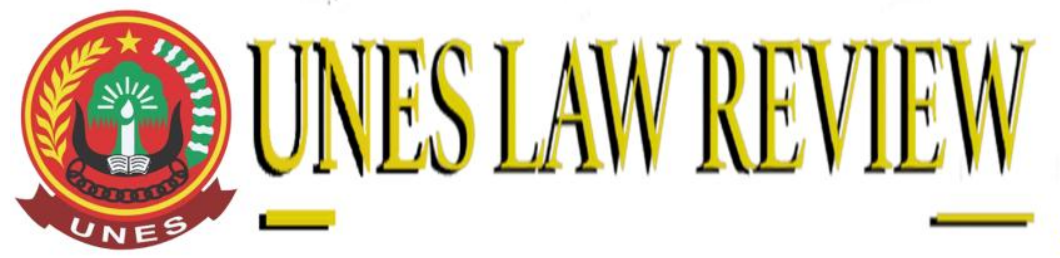

$+6281365118590$ $+6281365118590$

https://review-unes.com/ (2) uneslawreview@gmail.com @.

DOI: https://doi.org/10.31933/unesrev.v4i3

Diterima: 28/02/2022, Diperbaiki: 03/03/2022, Diterbitkan: 05/03/2022

\title{
PENERAPAN KLAUSULA BAKU PADA PRASYARAT JUAL BELI JUNK FOOD DITINJAU DARI HUKUM BISNIS
}

\author{
Fiona Vivian $^{1}$, Winda Fitri \\ ${ }^{1}$ Fakultas Hukum, Universitas Internasional Batam, Indonesia \\ Email: 1951077.fiona@uib.edu \\ ${ }^{2}$ Fakultas Hukum, Universitas Internasional Batam, Indonesia \\ Email:winda@uib.ac.id
}

Corresponding Author: Fiona Vivian

\begin{abstract}
The phenomenon of junk food is growing rapidly at this time. Although most junk food ultimately harms the health of consumers, buying and selling junk food is not illegal. As a general rule, both the seller and the buyer are free to determine the type, content and form of the contract. However, the existence of standard clauses as a means to facilitate sales transactions between producers and consumers has proven to be widely misused by sellers with standard clauses that are detrimental to consumers, such as "for take away food, an additional fee in the form of a takeaway charge is imposed." The application of the standard clause makes the seller has a stronger position and cause losses for the buyer. This type of research is normative legal research. The results show that basically the standard clause is not prohibited, as long as there are no elements that harm other parties. Provisions for the inclusion of standard clauses are regulated in Article 18 of the UU PERLINDUNGAN KONSUMEN. The advantage of using standard clauses in junk food agreements is that it gives consumers the benefits of time efficiency and equal service, but the disadvantage is that consumers do not have the opportunity to negotiate and decide on the contents of the contract, leaving only the choice of accept or leave. As a result, consumers become vulnerable, there is an imbalance of rights and obligations between economic actors and consumers, and consumers are more disadvantaged.
\end{abstract}

Keywords: Junk food, The Standard Clause, The Consumer

\section{ABSTRAK}

Fenomena junk food berkembang pesat pada saat ini. Meskipun kebanyakan makanan cepat saji pada akhirnya merugikan kesehatan konsumen, akan tetapi jual beli makanan cepat saji tidaklah illegal. Sebagai aturan umum, baik pihak penjual maupun pembeli bebas menentukan jenis, isi, dan bentuk kontrak. Namun adanya ketentuan klausula baku sebagai sarana untuk mempermudah transaksi penjualan antara produsen dan konsumen terbukti banyak disalahgunakan oleh penjual dengan klausula baku yang merugikan konsumen, seperti "untuk pengemasan makanan yang 
akan dibawa pulang dikenai biaya tambahan berupa biaya bungkus (takeaway charge)." Penerapan klausula baku membuat penjual berkedudukan lebih kuat dapat menimbulkan kerugian bagi pembeli karena kedudukan pembeli yang lemah, yaitu pembeli tidak dapat bertindak bebas tentang tawaran produk yang akan dibeli. Jenis penelitian ini adalah Penelitian Hukum Normatif. Hasil penelitian menunjukkan pada dasarnya klausula baku tidaklah dilarang, selama tidak ada unsur yang merugikan pihak lain. Ketentuan pencantuman klausula baku diatur dalam Pasal 18 UU Perlindungan Konsumen. Keuntungan penggunaan klausula baku pada perjanjian junk food adalah memberi konsumen manfaat efisiensi waktu dan layanan yang setara, tetapi kerugiannya adalah konsumen tidak memiliki kesempatan untuk bernegosiasi dan memutuskan isi kontrak, hanya menyisakan pilihan menerima atau pergi. Akibatnya konsumen menjadi rentan, terjadi ketidakseimbangan hak dan kewajiban antara pelaku ekonomi dan konsumen, dan konsumen lebih dirugikan.

Kata Kunci: Junk food, Klausula Baku, Konsumen

\section{PENDAHULUAN}

Manusia sebagai makhluk hidup membutuhkan berbagai hal guna menunjang kehidupannya. Salah satu kebutuhan paling mendasar yang harus dipenuhi adalah pangan atau makanan. Dewasa ini, untuk menemukan makanan di berbagai tempat tidaklah sulit, apalagi dengan keberadaan junk food atau makanan cepat saji. Fenomena junk food berkembang pesat pada saat ini. Hampir tidak ada tempat yang bebas dari salah satu restoran yang menawarkan makanan cepat saji. Konsep makanan cepat saji bukanlah hal baru. Amerika Serikat merupakan salah satu negara terkenal yang mengembangkan makanan ini selain Italia, Inggris dan beberapa negara Asia seperti Jepang dan China. Pada tahun 1867, seorang pria dari Jerman bernama Charles Mann Welt membuka penjualan sosis kecil di New York. Ide ini mendapat banyak permintaan dan kemudian menjadi lebih populer. Setelah itu, orang mulai mengenal dan membuat makanan cepat saji dimana saja dan kapan saja. ${ }^{1}$

Junk food juga dikenal dengan fast food atau makanan cepat saji dapat didefinisikan sebagai makanan yang banyak mengandung lemak dan gula, minyak, garam, berkalori tinggi, tetapi memiliki nilai gizi dan kualitas yang rendah. Misalnya untuk jenis makanan ini adalah chicken nugget, burger dan kentang goreng, keripik kaleng, pie, pizza dan minuman ringan. Awalnya, disebut makanan cepat saji karena mudah disiapkan dan dimakan. Sayangnya, kategori terbesar yang lebih menyukai makanan ini adalah anak-anak dan remaja yang membutuhkan lebih banyak makanan sehat untuk pertumbuhan mereka. Ada jutaan orang yang mengonsumsi jenis makanan ini setiap hari, namun banyak di antara mereka yang tidak memperhatikan sumber, cara pembuatan, dan efeknya bagi tubuh.

Meskipun makanan cepat saji adalah bagian utama dari kehidupan kita sekarang karena beberapa faktor seperti gaya hidup, nilai, dan iklan komersial yang besar, makanan cepat saji memiliki efek negatif yang serius pada kesehatan kita dan keluarga. Terkadang junk food dianggap sebagai solusi sementara karena rasanya yang enak dan mudah dibuat. Faktanya, komunitas dan pasarnya mengalami peningkatan yang signifikan dalam ukuran makanan cepat

\footnotetext{
${ }^{1}$ Eman Al-Saad, Causes And Effects Of Junk food, International Journal Of Scientific \& Technology Research Volume 5, Issue 04, April 2016, hlm. 279.
} 
saji, dan permintaan yang besar oleh salah satu alasan utama yang telah membantu menyebarkan rantai restoran cepat saji di seluruh dunia. Salah satu penyebab utama penyebaran makanan cepat saji adalah gaya hidup yang berbeda antara masa lalu dan masa kini dalam berbagai aspek seperti ritme kehidupan yang dapat dibagi menjadi dua gaya utama: gaya terburu-buru dan gaya sedentary. $^{2}$

Gaya pertama adalah gaya terburu-buru yang menunjukkan bagaimana orang sibuk dan menjaga waktu dan sesuai dengan cara hidup mereka. "Irama kehidupan modern memberikan nilai yang tinggi pada setiap momen. Oleh karena itu, setiap orang berusaha untuk mendapatkan tambahan waktu untuk bekerja, rekreasi, atau keluarga. Salah satu cara menghemat waktu adalah dengan menggunakan layanan makanan cepat saji yang menawarkan harga lebih murah daripada kafe konvensional dan restoran."3 Gaya hidup yang terburu-buru atau cepat yang kita jalani saat ini memberikan banyak variabel pada gaya hidup. Orang-orang kehilangan banyak kebiasaan dalam kehidupan sehari-hari mereka, karena kebiasaan baru yang masuk dan mengontrol cara hidup mereka. Seperti gaya hidup serba cepat yang kini menguasai kita di tempat kerja dan di rumah sekaligus, berdampak pada hubungan seseorang dengan orang-orang di sekitarnya, serta hubungannya dengan dirinya sendiri, membuat mereka banyak mengerjakan tugas sendiri karena terburu-buru. keterbatasan waktu dan banyaknya kekhawatiran. Akibatnya, orang yang terburuburu tidak memiliki waktu yang cukup untuk memasak untuk keluarga, karena waktu menjadi sesuatu yang penting. Di sisi lain, gaya hidup sedentary yang merupakan jenis gaya hidup kedua sangat berbeda dengan gaya hidup pertama. Gaya hidup semacam ini menunjukkan bagaimana orang suka menghabiskan banyak waktu untuk mengatur atau tidak melakukan apa-apa. Dengan kata lain, gaya hidup ini berarti kemalasan. Menghabiskan berjam-jam di depan TV atau layar komputer bisa menjadi alasan paling populer dalam kasus seperti itu. Selain itu, orang dapat membuat pesanan makanan mereka melalui internet pada saat yang sama ketika melakukan pekerjaan mereka di komputer. Junk food adalah makanan paling mudah dan cepat melengkapi gambaran gaya hidup jenis ini.

Penyebab kedua menyebarnya makanan cepat saji adalah nilai makanan ini yang dapat dibagi menjadi tiga bagian utama. Ketiga bagian tersebut adalah: harga yang murah, rasa yang enak dan mudah didapat. Sebagian besar restoran cepat saji memberikan harga yang berbeda, tetapi secara keseluruhan dianggap wajar dan murah. Harga makanan ini sangat menguntungkan, sehingga semua orang dapat membeli makanan cepat saji. Alasan rendahnya harga makanan cepat saji bisa jadi terbuat dari bahan berkualitas buruk. Karena pengawasan kesehatan yang buruk di beberapa negara, beberapa perusahaan makanan mengambil keuntungan untuk menjual makanan buruk mereka kepada konsumen. Akibatnya, mereka mengendalikan biaya bahan utama makanan cepat saji untuk mencapai keuntungan maksimal dari makanan berkualitas rendah.

Banyak orang menyukai junk food karena rasanya yang enak. Junk food memiliki cita rasa yang berbeda dan istimewa karena banyak mengandung rempah-rempah yang membuatnya

${ }^{2}$ Ibid.

${ }^{3}$ Lauva, Zinta, and Velta Basevica. (2012). "Causes Of LongTerm Consumption And Popularity Of Offers In Junk food Companies." Economic Science For Rural Development Conference Proceedings 29 hlm. 37- 40. 
enak. Salah satu bahan yang paling penting adalah Monosodium Glutamat. Menurut US Food and Drug Administration pembuat makanan menambahkan Monosodium Glutamat ke makanan untuk meningkatkan dan memperkuat rasa. ${ }^{4}$ Namun, banyak penelitian yang membuktikan bahwa Monosodium Glutamat sangat berbahaya bagi kesehatan dan memiliki banyak efek tidak menyehatkan bagi tubuh. Selain itu, makanan cepat saji mengandung banyak lemak untuk membuat makanan lebih enak.

Sebagian besar jalan memiliki lebih dari satu restoran cepat saji. Alhasil, masyarakat di mana saja bisa mendapatkan makanan cepat saji dengan mudah. Apalagi karena banyaknya restoran yang menawarkan layanan pesan antar, makanan menjadi lebih mudah didapat kapan saja. Penyebab ketiga dari penyebaran makanan cepat saji adalah iklan komersial yang menggunakan teknologi baru seperti internet atau media biasa seperti TV, majalah atau surat kabar untuk menarik pelanggan. Iklan komersial merupakan salah satu cara yang paling efisien untuk mempromosikan makanan cepat saji, karena memiliki efek yang cukup siginifikan untuk mempengaruhi banyak orang. Iklan-iklan ini mempengaruhi orang secara langsung dengan mengarahkan orang membeli makanan ini atau secara tidak langsung pada kebiasaan diet, tren dan akhirnya mengubah perilaku masyarakat dalam hal konsumsi makanan.

Perusahaan makanan cepat saji secara global menghabiskan jutaan dolar untuk mengiklankan makanan mereka kepada konsumen. Sayangnya, anak-anak lebih terpengaruh oleh iklan komersial karena beberapa alasan. Mereka tidak memiliki kemampuan kognitif untuk memahami fakta di balik iklan komersial. ${ }^{5}$ Selain itu, mereka lebih dipengaruhi oleh cara pengiklan menggunakan makanan cepat saji dengan memberi hadiah mainan. Padahal, mainan yang diberikan oleh restoran cepat saji itu sangat murah dan terbuat dari bahan berkualitas rendah yang berada di bawah standar kesehatan. Beberapa bahan ini dapat menyebabkan beberapa penyakit kanker. Lebih dari itu, restoran cepat saji menyediakan area bermain untuk anak-anak di samping makanan untuk mendorong seluruh keluarga menghabiskan lebih banyak waktu dan datang lagi ke restoran di masa mendatang. Akibatnya, makan makanan cepat saji memiliki efek serius dalam berbagai aspek dalam kehidupan manusia. Dimulai dengan kesehatan mereka dan berakhir dengan masyarakat secara keseluruhan. Meskipun makanan tersebut terbukti membuat kerusakan kesehatan yang sangat serius, yang mana dokter memperingatkan orang-orang mengenai apa yang menyebabkan kerusakan serius pada tubuh dan memainkan peran kunci dalam penyakit di era ini, banyak orang di berbagai usia bergantung pada makanan cepat saji pada makanan sehari-hari mereka.

Meskipun kebanyakan makanan cepat saji pada akhirnya merugikan kesehatan konsumen, akan tetapi jual beli makanan cepat saji tidaklah illegal. Sebagai aturan umum, baik pihak penjual maupun pembeli bebas menentukan jenis, isi, dan bentuk kontrak. Adanya kebebasan perjanjian antara penjual dan pembeli sebenarnya merupakan perjanjian yang memuat syarat-syarat yang membatasi kewajiban, menghilangkan kewajiban, membebaskan kewajiban, mengurangi kewajiban, dan membebaskan salah satu pihak dari kewajiban. Adanya ketentuan

\footnotetext{
${ }^{4}$ Food and Drug Administration http://www.fda.gov, diakses pada 26 Januari 2022.

${ }^{5}$ Bernhardt, Amy M., et al.(2013) "How Television Junk food Marketing Aimed At Children Compares With Adult Advertisements." Plos ONE 8.8 hlm. 1-6.
} 
klausula baku sebagai sarana untuk mempermudah transaksi penjualan antara produsen dan konsumen terbukti banyak disalahgunakan oleh penjual restoran cepat saji dengan memberlakukan persyaratan yang sangat tidak menguntungkan bagi konsumen. Salah satu bunyi dari klausa baku adalah "untuk pengemasan makanan yang akan dibawa pulang dikenai biaya tambahan berupa biaya bungkus (takeaway charge)."

Penerapan klausa baku membuat penjual berkedudukan lebih kuat dapat menimbulkan kerugian yang sangat besar bagi pembeli karena kedudukan pembeli yang lemah, yaitu pembeli tidak dapat bertindak bebas tentang tawaran produk yang akan dibeli. Untuk mengatur hal tersebut maka negara membentuk Undang-Undang Perlindungan Konsumen. Dalam UndangUndang Perlindungan Konsumen, ketentuan klausula baku ini merupakan Bab V tentang ketentuan yang memuat klausula baku yang hanya terdiri dari satu klausul, yaitu Pasal 18 Undang-Undang Nomor 8 Tahun 1999 tentang Perlindungan Konsumen. Di regulasi Pasal 18 undang-undang ini pada dasarnya mengatur dua jenis larangan yang berlaku bagi pelaku usaha yang mengadakan kontrak atau klausul baku. Pasal 18 (1) mengatur tentang larangan pencantuman klausa baku, dan Pasal 18 (2) mengatur tentang bentuk dan jenis serta ejaan klausa baku yang dilarang.

Berdasarkan latar belakang tersebut di atas, maka dalam jurnal ini penulis mengambil judul Penerapan Klausula Baku Pada Prasyarat Jual Beli Junk food Ditinjau Dari Hukum Bisnis. Berdasarkan uraian latar belakang yang dikemukakan di atas, maka penulis mengambil beberapa permasalahan yang sesuai dengan penulisan ini, adalah sebagai berikut:

1. Bagaimana penerapan klausula baku pada prasyarat jual beli Junk food?

2. Bagaimana tinjauan hukum bisnis terhadap penerapan klausula baku pada prasyarat jual beli Junk food?

3. Bagaimana akibat hukum pada penerapan klausula baku prasyarat jual beli Junk Food?

\section{METODE PENELITIAN}

Berdasarkan Kamus Oxford, penelitian berarti penyelidikan sistematis dan studi bahan dan sumber untuk membangun fakta dan mencapai kesimpulan baru. Menurut Soerjono Soekanto, penelitian adalah suatu kegiatan ilmiah yang didasarkan pada analisis dan merupakan suatu konstruksi yang dilakukan dengan sistematis, metodologis dan konsisten. Pembaca perlu memahami apa yang dibahas dalam suatu penelitian hukum. Dan objek penelitian hukum adalah masalah hukum. Fakta yang terjadi di masyarakat dan tidak selaras dengan hukum, yaitu masalah hukum.

Jenis penelitian ini adalah Penelitian Hukum Normatif. Penelitian hukum normatif adalah penelitian yang menggunakan hukum sebagai landasan norma. Artinya penelitian ini didasarkan pada penelitian kepustakaan yang berfokus pada membaca dan menganalisis bahan primer dan sekunder. ${ }^{6}$ Dalam penelitian ini, penulis menggambarkan kasus, mencari, dan mengolah berbagai

\footnotetext{
${ }^{6}$ Johnny Ibrahim, 2006, Teori dan Metodologi Penelitian Hukum Normatif, Second Edition, Malang: Bayu Media, hlm. 46
} 
data dari studi dokumen (perpustakaan) dan menghasilkan laporan hasil penelitian. Menurut Jacob dan Mersky, penelitian hukum normatif berusaha menemukan otoritas-otoritas tersebut dalam sumber-sumber utama hukum yang dapat diterapkan pada situasi tertentu. Penelitian selalu berorientasi pertama pada sumber primer wajib, yaitu ketentuan konstitusional atau undang-undang dari legislatif, dan keputusan pengadilan dari yurisdiksi yang terlibat. Penelitian kemudian berfokus pada menemukan otoritas utama persuasif yang terdiri dari keputusan dari pengadilan yurisdiksi hukum umum lainnya. Apabila proses pencarian hukum terhadap sumber hukum primer tidak ditemukan, maka pencari akan mencari sumber hukum sekunder. ${ }^{7}$ Dalam kaitannya dengan penelitian hukum normatif peneliti menggunakan beberapa pendekatan yaitu Statute Approach dan Case Approach. Sebuah penelitian hukum normatif harus menggunakan pendekatan undang-undang tentunya karena dalam pendekatan ini peneliti mengkaji berbagai aturan hukum serta tema sentralnya menjadi fokus penelitian. ${ }^{8}$ Pendekatan Kasus bertujuan untuk mempelajari penerapan norma atau aturan hukum yang dilakukan dalam praktik hukum.

Jenis bahan hukum yang penulis gunakan adalah bahan hukum primer dan sekunder. Bahan hukum primer ini terdiri dari peraturan perundang-undangan, dokumen resmi, yuridprudensi, dan sebagainya. Bahan hukum primer yang penulis gunakan dalam penelitian ini adalah Undang-Undang Dasar Republik Indonesia Tahun 1945; Kitab Undang-Undang Hukum Perdata; Undang-Undang Nomor 8 Tahun 1999 Perlindungan Konsumen; serta Peraturan Menteri Negri Pekerjaan Umum dan Perumahan Rakyat Nomor 11/PRT/M/2019 tentang Sistem Perjanjian Pengikatan Jual Beli. Bahan hukum sekunder merupakan bahan latar yang menggambarkan suatu bidang hukum. Sumber-sumber tersebut merinci dan memberikan konteks pada masalah hukum yang sedang diteliti dan mengidentifikasi undang-undang dan peraturan yang relevan dan kasus-kasus terkemuka. Sumber-sumber sekunder bukanlah hukum itu sendiri. Sebaliknya, bahan hukum sekunder adalah cara yang membantu untuk mendapatkan gambaran umum tentang suatu bidang hukum, untuk mendapatkan perspektif tentang bagaimana masalah spesifik peneliti sesuai dengan konteks hukum yang lebih luas, dan untuk mendapatkan referensi ke sumber utama utama untuk suatu bidang hukum. Sumber sekunder seringkali menjadi awal untuk memulai penelitian hukum. Bahan hukum sekunder dalam penelitian ini adalah buku-buku ilmiah dalam bidang hukum, makalah-makalah, jurnal ilmiah, dan artikel ilmiah. Untuk mengumpulkan bahan-bahan hukum tersebut, penulis menggunakan Teknik pengkajian atas materi serta melakukan telaah terhadap data-data yang didapatkan.

\section{HASIL DAN PEMBAHASAN}

\section{Penerapan Klausula Baku Pada Prasyarat Jual Beli Junk food}

Junk food atau makanan cepat saji berkembang pesat sejak tahun 1996. Pertumbuhan tersebut menyadarkan masyarakat akan makanan yang disajikan oleh merek internasional dan nasional. Makanan cepat saji telah mengubah budaya makan di luar selama beberapa tahun terakhir. Makanan cepat saji sekarang tersedia di setiap mal, bandara, dan stasiun kereta api dan

\footnotetext{
${ }^{7}$ Ibid, hlm. 45 .

${ }^{8}$ Ibid, hlm. 302.
} 
di hampir setiap jalan. Istilah 'junk food' digunakan untuk menggambarkan makanan yang nilai gizinya lebih rendah, tetapi nilai kalorinya relatif lebih tinggi.

Fatima dan Shrivastava menyatakan definisi Junk food sebagai makanan berkalori kosong yang merupakan makanan berkalori tinggi atau kaya kalori yang kekurangan zat gizi mikro seperti vitamin, mineral atau asam amino dan serat tetapi memiliki energi (kalori) yang tinggi. ${ }^{9}$ Makanan ini tidak mengandung nutrisi yang dibutuhkan tubuh kita untuk tetap sehat. Oleh karena itu jenis makanan ini memiliki nilai gizi yang buruk yang dianggap tidak sehat dan dapat disebut sebagai junk food atau makanan sampah.

Makanan cepat saji mulai menarik minat anak-anak dan remaja yang mencari makanan dengan harga lebih murah. Merek-merek seperti Dominos Pizza, Pizza Hut, McDonald, Subway, dan KFC adalah yang mulai menyajikan makanan cepat saji dari negara barat seperti burger, pizza, ayam tepung, nugget, dan sebagainya. Hyde menyebutkan bahwa perilaku konsumen sangat penting bagi semua perusahaan untuk menjual produk di pasar. ${ }^{10}$ Setiap pelanggan mencari berbagai produk baru di pasar untuk mencoba sesuatu yang baru. Alasan di balik ini adalah berbagai rangsangan seperti iklan, promosi penjualan dll. Kesukaan terhadap makanan cepat saji meningkat karena kedekatan outlet, lokasi yang tepat, kemasan yang menarik, dan penawaran yang sangat baik. Banyak orang mencoba untuk menghindari atau membatasi makanan seperti itu dalam diet mereka, karena khawatir itu tidak sehat, tetapi meskipun faktanya banyak produsen makanan memproduksi berbagai produk yang dapat dianggap sampah, tetapi jumlah orang yang makan sampah masih sangat banyak. tinggi.

Konsumsi junk food yang berlebihan mengundang berbagai penyakit seperti hipertensi, tekanan darah, kanker, dan lain-lain. Produk junk food mengandung bahan kimia yang tinggi, pewarna dan minyak/lemak yang berlebih sehingga junk food dianggap sebagai junk food. Merek makanan cepat saji menyadari bahwa isu Kesehatan mengenai makanan cepat saji membunuh bisnis mereka, sehingga nama baru untuk seluruh segmen diberikan yaitu Restoran Layanan Cepat. $^{11}$

Meskipun terbukti menimbulkan beberapa penyakit, akan tetapi pada dasarnya jual beli junk food adalah sah secara hukum bisnis. Dewasa ini, kondisi masyarakat tidak dapat dipisahkan dari kebutuhan masyarakat akan jual beli junk food. Perlindungan hukum akan selalu diberikan secara adil dan menyeluruh apabila ada kejujuran dan/atau itikad baik dalam pelaksanaan jual beli karena cara tersebut juga merupakan faktor yang sangat penting, sedangkan yang tidak beritikad baik tidak dapat dikatakan sebagai perjanjian yang sah. Jual beli menurut Pasal 1457 KUHPerdata atau Kitab Undang-undang Hukum Perdata, yang selanjutnya disingkat KUHPdt adalah perjanjian timbal balik antara berbagai pihak yang dianggap menjual barangnya (penjual) dalam hal ini untuk saling berjanji untuk dapat menyerahkan hak atas hartanya akan

\footnotetext{
${ }^{9}$ Fatima, A. \& Srivastava, S. (2017). Impact of Junk food on Health. International Journal of Applied Social Science, 4 (9\&10), pp. 350-354

${ }^{10}$ Hyde, A.M., Jain, D., Verma, S.K. \& Jain, A. (2017). A Study of Exploratory Buying Behavior Tendencies in FMCG Sector. International Journal on Recent Trends in Business and Tourism, 1(2), pp 16-27.

${ }^{11}$ Prachi Hajare Wani \& Nandkishor Sarode, Impact Of Junk food Consumption On Health, International Journal on Recent Trends in Business and Tourism, Vol. 2 (3) 2018.
} 
dari suatu benda atau barang, dan pihak dari yang satu atau yang lain dalam hal ini (pembeli) juga berjanji untuk membayar dari semua ketentuan harga yang memang terdiri dari suatu harga atau uang di atas sebagai bentuk ganti rugi atas perolehan hak milik, dengan kata lain jual beli merupakan suatu perjanjian dengan mana pihak yang satu mengikatkan dirinya untuk menyerahkan suatu kebendaan, dan pihak yang lain untuk membayar harga yang telah dijanjikan.

Dalam perjanjian jual beli di junk food, tak jarang pula terdapat klausula baku yang terkadang merugikan konsumen. Mengenai klausula baku ini diatur dalam Undang-Undang Perlindungan Konsumen, yang mendefinisikan klausula baku sebagai setiap aturan atau ketentuan dan syarat-syarat yang telah dipersiapkan dan ditetapkan terlebih dahulu secara sepihak oleh pelaku usaha yang dituangkan dalam suatu dokumen dan/atau perjanjian yang mengikat dan wajib dipenuhi oleh konsumen. ${ }^{12}$ Penerapan klausula baku dalam prasyarat jual beli junk food biasanya dilakukan oleh restoran dengan mengenai biaya tambahan (charge) saat konsumen membungkus makanannya. Hal ini di luar sepengetahuan konsumen tentang adanya aturan tersebut. Tidak ada pemberitahuan terlebih dahulu dari pelayan yang bekerja berkaitan dengan hal tersebut dan konsumen hanya mengetahui hal tersebut ketika hendak membungkus makanannya. Tentu saja hal tersebut membuat konsumen mau tidak mau harus membayar charge yang dikenakan dan dapat dikatakan penggunaan klausula baku semacam ini merugikan konsumen. Seharusnya, konsumen memiliki hak untuk diberi opsi dan mendapat informasi yang benar, dan konsumen tidak boleh dirugikan sepihak karena adanya aturan klausula baku.

Tinjauan Hukum Bisnis Terhadap Penerapan Klausula Baku Pada Prasyarat Jual Beli Junk food

Junk food merupakan salah satu bisnis yang menjanjikan pada era ini. Kehidupan masyarakat yang cenderung berubah dan lebih menginginkan segala hal secara instan membuat bisnis junk food sangat digemari. Namun terlepas dari kecintaan masyarakat akan konsumsi junk food, tidak jarang pula pelaku bisnis menerapkan klausula baku pada perjanjian jual beli yang merugikan konsumennya. Untuk itulah, hukum bisnis hadir untuk mengatur tentang tata cara pelaksanaan urusan atau kegiatan dagang, termasuk junk food. Di Indonesia sendiri, salah satu sumber hukum bisnis adalah KUHPerdata termasuk UU Perlindungan Konsumen.

Sebelum perlindungan konsumen secara tegas dikenal dan dikembangkan, pengertian konsumen lebih cenderung identik dengan pengertian masyarakat dalam perkembangan hal-hal yang berkaitan dengan masalah industri, perdagangan, kesehatan dan keamanan. Hal-hal tersebut di atas akhirnya melahirkan suatu peraturan tentang Perlindungan Konsumen (UU Nomor 8 Tahun 1999; Lembaran Negara Tahun 1999 Nomor 42). Untuk memenuhi butir-butir filosofis tersebut, Undang-Undang Republik Indonesia Nomor 8 Tahun 1999 (untuk selanjutnya disebut UU Perlindungan Konsumen) menegaskan bahwa perlindungan konsumen Indonesia didasarkan pada manfaat, keadilan, keseimbangan, keamanan dan keselamatan, serta kepastian hukum (pasal 2 dan penjelasan pasal). Jadi, tergambar bahwa rasio UU Perlindungan Konsumen adalah: (a) Menyeimbangkan daya tawar konsumen terhadap pelaku usaha; dan (b) Mendorong pelaku

\footnotetext{
${ }^{12}$ Pasal 1 angka 10 Undang-Undang Nomor 8 Tahun 1999 Tentang Perlindungan Konsumen
} 
usaha untuk jujur dan bertanggung jawab dalam menjalankan kegiatannya. UU Perlindungan Konsumen lahir sebagai jawaban atas perkembangan dan perkembangan perekonomian saat ini. Konsumen sebagai motor penggerak perekonomian seringkali berada pada posisi yang lemah atau tidak seimbang jika dibandingkan dengan pelaku usaha dan hanya menjadi alat dalam kegiatan usaha untuk meraup keuntungan sebesar-besarnya oleh pelaku usaha. ${ }^{13}$

Berdasarkan penjelasan umum UU Perlindungan Konsumen disebutkan bahwa faktor utama yang menjadi kelemahan konsumen dalam berdagang adalah tingkat kesadaran konsumen yang masih sangat rendah yang selanjutnya diketahui terutama karena rendahnya kesadaran konsumen dalam bertransaksi, terlebih ketika ada klausula baku. Merujuk pada hal tersebut, UU Perlindungan Konsumen diharapkan dapat menjadi landasan hukum yang kuat bagi pemerintah dan lembaga perlindungan konsumen non pemerintah untuk melakukan upaya pemberdayaan konsumen melalui pembinaan dan edukasi konsumen. Sehingga diharapkan semua kepentingan konsumen secara integratif dan komprehensif dapat terlindungi yang pada gilirannya dapat meningkatkan kesejahteraan masyarakat Indonesia.

Konsumen adalah semua pengguna barang dan/atau jasa yang tersedia di masyarakat, baik untuk kepentingan sendiri, keluarga, orang lain, dan makhluk hidup lainnya dan bukan untuk diperdagangkan. Lebih lanjut, UU Perlindungan Konsumen menekankan pengertian 'perlindungan konsumen' itu sendiri sebagai segala upaya yang menjamin kepastian hukum untuk memberikan perlindungan kepada konsumen. Artinya undang-undang ini menjamin kepatuhan hukum kepada pengguna akhir suatu produk berupa barang dan jasa yang beredar di masyarakat. ${ }^{14}$

Suatu perjanjian yang dibuat oleh seseorang dengan orang lain atau lebih akan menimbulkan suatu hubungan hukum yang disebut perikatan. Jadi dapat dikatakan bahwa persetujuan adalah sumber dari suatu perjanjian. Menurut pasal 1320 KUHPdt suatu perjanjian harus memenuhi syarat sahnya perjanjian, yaitu adanya kesepakatan para pihak, kecakapan para pihak dalam membuat perjanjian, adanya hal tertentu, dan terdapat suatu sebab yang diperkenankan. Dengan demikian akan terpenuhi sesuatu 4 (empat) dari syarat sahnya isi perjanjian yang mengikat, perjanjian itu dianggap sah dan mengikat para pihak yang membuatnya karena itulah alasan adanya undang-undang dan akibatnya terhadap perjanjian. ${ }^{15}$ Dengan demikian, dalam jual beli makanan cepat saji, tentunya juga terjadi perjanjian yang sah antara penjual dengan pembeli.

Dalam hukum kontrak akan ada suatu asas dan yang dipenuhi oleh berbagai pihak antara lain adanya asas dan kebebasan dalam membuat kontrak atau dan asas yang beritikad baik yaitu kehendak masing-masing pihak yang akan selalu diwujudkan. dalam arti perjanjian atau kesepakatan adalah dimana merupakan bentuk dasar pengikatan suatu prosedur perjanjian dalam

\footnotetext{
${ }^{13}$ Hamzah, Comparative Study on Consumer Protection in Indonesia through Mechanism of Product Liability Insurance, European Research Studies Journal Volume XX, Issue 3A, 2017, pp. 706-716.

${ }^{14}$ Ahmadi Miru \& Sutarman Yodo, Hukum Perlindungan Konsumen, PT. RajaGrafindo Persada, Jakarta, 2004, hlm. 35-37; Sunaryati Hartono, Hukum Ekonomi Pembangunan Indonesia, Bandung, BPHN \& Binacipta, 1988, hlm. 4446.

${ }^{15}$ Fransiska Novita Eleanora, Goods Selling-Buying Agreement and Legal Protection for Sellers, Lentera Hukum, Volume 6 Issue 1 (2019), pp. 133-140.
} 
suatu ketentuan hukum dan kontraktual yang ada. Akibat hukum yang telah mengikat para pihak, dinyatakan secara lisan dan tertulis.

Menurut pasal 1338 ayat 1 KUHPdt, asas kebebasan dan kontrak dibuat secara sah, itulah yang dimaksud dengan perjanjian, dan sangat mengikat atas hukum antara para pihak dan atau yang telah membuatnya. Selanjutnya Pasal 1338 ayat 3 KUHPerdata menyatakan bahwa itikad baik harus selalu ada jika hendak melaksanakan suatu atau setiap perjanjian. Kepentingan pembeli adalah kepentingan penjual dalam melaksanakan haknya dan dalam situasi serta kondisi tertentu. Jangan sampai seorang pembeli meminta dan menuntut haknya dalam waktu yang sulit bagi seorang penjual karena adanya itikad buruk atau cacat hukum. Dengan demikian, jika rasa keadilan dianggap dilanggar karena menimbulkan ketidakseimbangan akibat pelaksanaan isi perjanjian yang mengandung klausula baku yang dibuat demi kepentingan restoran junk food sepihak, maka dalam hal ini dapat dilakukan atau akan melakukan penyesuaian mengenai kewajiban dan hak yang telah tertuang dalam perjanjian. Dalam prakteknya, itikad yang baik bukan pada saat pelaksanaan perjanjian, tetapi pada saat perjanjian dibuat atau ditandatangani. ${ }^{16}$

Perjanjian menciptakan ikatan bagi para pihak dalam perjanjian. Perjanjian tersebut berlangsung berdasarkan asas kebebasan berkontrak antara dua pihak yang memiliki kedudukan yang seimbang.ini dalam perkembangannya menjadi paradigma baru dalam hukum kontrak yang mengarah pada kebebasan tanpa batas (unretristicted freedom of contract). ${ }^{17}$ Perjanjian harus memenuhi syarat sahnya perjanjian sebagaimana diatur dalam Pasal 1320 KUHPdt, adanya kesepakatan para pihak, kecakapan para pihak dalam membuat perjanjian, adanya hal tertentu, dan terdapat suatu sebab yang diperkenankan. Kesepakatan itu dilakukan dengan memenuhi kebebasan berkontrak yang menjamin tidak ada paksaan, penipuan atau pengawasan. Namun prinsip kebebasan untuk kondisi sekarang ini membuat orang/pihak yang kuat dapat memaksakan kehendaknya kepada pihak yang lemah, sehingga cita-cita kebebasan berkontrak yang pada awalnya memberikan keseimbangan hukum, kepentingan dan juga keseimbangan dalam tawar menawar. posisi, menjadi alat pemaksaan bagi pihak yang lemah.

\section{Akibat Hukum Pada Penerapan Klausula Baku Prasyarat Jual Beli Junk Food}

Dalam kegiatan jual beli junk food, masalah hukum bisa muncul, misalnya jika masih ada kerugian sepihak dalam perjanjian jual beli junk food. Kerugian ini dapat dialami konsumen apabila ada klausula baku yang dibuat sepihak oleh penjual junk food. Dalam klausula baku yang mewajibkan konsumen untuk membayar biaya bungkus tentunya sangat merugikan konsumen, terutama saat tidak ada pemberitahuan sebelumnya. Pada dasarnya klausula baku tidaklah dilarang, selama tidak ada unsur yang merugikan pihak lain. Ketentuan pencantuman klausula baku diatur dalam Pasal 18 UU PERLINDUNGAN KONSUMEN.

Klausula baku berarti perjanjian bahwa hampir semua klausul distandarisasi oleh produsen dan konsumen pada dasarnya tidak memiliki kesempatan untuk bernegosiasi atau meminta perubahan. Adapun apa yang belum distandarisasi hanya beberapa hal, misalnya yang

\footnotetext{
${ }^{16}$ Suharnoko, Hukum Perjanjian (Teori dan Analisa Kasus), Kencana, Jakarta, 2008, hlm. 1-4.

17 Celina Tri Siwi Kristiyanti, Fulfillment Of Good Faith Principle In Preparation Of Standard Clauses, Jurnal Notariil, Vol. 4, No. 2, November 2019, 114-122.
} 
berkaitan dengan jenis, harga, kuantitas, warna, tempat, waktu, dan beberapa hal spesifik dari yang dijanjikan benda. Sjahdeni menekankan, yang menjadi standarisasi bukan hanya perjanjian saja, tetapi juga klausa. ${ }^{18}$ Penggunaan klausula baku / kontrak standar dalam bisnis makanan cepat saji adalah legal karena diizinkan oleh undang-undang, tepatnya diatur dalam UndangUndang Perlindungan Konsumen. Ada pro dan kontra untuk menggunakan kontrak standar / standar dalam makanan cepat saji. Keuntungannya adalah memberi konsumen manfaat efisiensi waktu dan layanan yang setara, tetapi kerugiannya adalah konsumen tidak memiliki kesempatan untuk bernegosiasi dan memutuskan isi kontrak, hanya menyisakan pilihan menerima atau pergi. Akibatnya konsumen menjadi rentan, terjadi ketidakseimbangan hak dan kewajiban antara pelaku ekonomi dan konsumen, dan konsumen lebih dirugikan. ${ }^{19}$

Penggunaan standar / kontrak standar diperbolehkan dan diatur oleh undang-undang perlindungan konsumen. Pasal 18 UU Perlindungan Konsumen mengatur pencantuman klausula baku dalam standar/kontrak baku yang digunakan pelaku usaha ekonomi dalam kegiatan usahanya. Di dalam Pasal 18 (1) UU Perlindungan Konsumen mengatur tentang pencantuman klausula baku yang dilarang untuk dicantumkan, diantaranya klausula pengalihan tanggung jawab atau eksonerasi. Pasal 18 ayat (2) UU Perlindungan Konsumen mengatur tentang larangan pencantuman klausula baku yangl etaknya sulit terlihat dan terbaca jelas, dan ayat (3) menentukan bahwa jika klausula baku yang dicantumkan melanggar ketentuan ayat (1) dan (2) maka klausula baku tersebut batal demi hukum.

\section{KESIMPULAN}

Dalam perjanjian jual beli di junk food, tak jarang pula terdapat klausula baku yang terkadang merugikan konsumen. Penerapan klausula baku dalam prasyarat jual beli junk food biasanya dilakukan oleh restoran dengan mengenai biaya tambahan (charge) saat konsumen membungkus makanannya. Hal ini di luar sepengetahuan konsumen tentang adanya aturan tersebut. Tidak ada pemberitahuan terlebih dahulu dari pelayan yang bekerja berkaitan dengan hal tersebut dan konsumen hanya mengetahui hal tersebut ketika hendak membungkus makanannya. Tentu saja hal tersebut membuat konsumen mau tidak mau harus membayar charge yang dikenakan dan dapat dikatakan penggunaan klausula baku semacam ini merugikan konsumen. Pada dasarnya klausula baku tidaklah dilarang, selama tidak ada unsur yang merugikan pihak lain. Ketentuan pencantuman klausula baku diatur dalam Pasal 18 UU Perlindungan Konsumen.

Penggunaan perjanjian standar/ baku di junk food memiliki kelebihan dan kekurangan, kelebihan atau keuntungannya adalah memberi konsumen manfaat efisiensi waktu dan layanan yang setara, tetapi kerugiannya adalah konsumen tidak memiliki kesempatan untuk bernegosiasi dan memutuskan isi kontrak, hanya menyisakan pilihan menerima atau pergi. Akibatnya

\footnotetext{
${ }^{18}$ Sjahdeni, S. R. (1993). Kebebasan Berkontrak dan Perlindungan yang Seimbang Bagi Para Pihak dalam Kontrak Kredt Bank di Indonesia. Jakarta: Institut Bankir Indonesia.

${ }^{19}$ Sriwati. (2000). Perlindungan Hukum Bagi Para Pihak Dalam Perjanjian Baku. Jurnal Yustika: Media Hukum Dan Keadilan, 3(2).
} 
konsumen menjadi rentan, terjadi ketidakseimbangan hak dan kewajiban antara pelaku ekonomi dan konsumen, dan konsumen lebih dirugikan.

\section{DAFTAR PUSTAKA}

Ahmadi Miru \& Sutarman Yodo. (2004). Hukum Perlindungan Konsumen, PT. RajaGrafindo Persada, Jakarta.

Johnny Ibrahim. (2006). Teori dan Metodologi Penelitian Hukum Normatif, Second Edition, Malang: Bayu Media.

Sjahdeni, S. R. (1993). Kebebasan Berkontrak dan Perlindungan yang Seimbang Bagi Para Pihak dalam Kontrak Kredt Bank di Indonesia. Jakarta: Institut Bankir Indonesia.

Suharnoko. (2008). Hukum Perjanjian (Teori dan Analisa Kasus), Kencana, Jakarta.

Sunaryati Hartono. (1988). Hukum Ekonomi Pembangunan Indonesia, Bandung, BPHN \& Binacipta.

Bernhardt, Amy M., et al. (2013). How Television Junk food Marketing Aimed At Children Compares With Adult Advertisements. Plos ONE 8.8.

Celina Tri Siwi Kristiyanti. (2019). Fulfillment Of Good Faith Principle In Preparation Of Standard Clauses, Jurnal Notariil, 4 (2), 114-122.

Eman Al-Saad. (2016). Causes And Effects Of Junk food, International Journal Of Scientific \& Technology Research 5 (4).

Fatima, A. \& Srivastava, S. (2017). Impact of Junk food on Health. International Journal of Applied Social Science, 4 (9\&10).

Fransiska Novita Eleanora. (2019). Goods Selling-Buying Agreement and Legal Protection for Sellers, Lentera Hukum, 6 (1), 133-140.

Hamzah. (2017) Comparative Study on Consumer Protection in Indonesia through Mechanism of Product Liability Insurance, European Research Studies Journal Volume XX, Issue 3A, 706-716.

Hyde, A.M., Jain, D., Verma, S.K. \& Jain, A. (2017). A Study of Exploratory Buying Behavior Tendencies in FMCG Sector. International Journal on Recent Trends in Business and Tourism, 1(2).

Lauva, Zinta, and Velta Basevica. (2012). "Causes Of Long Term Consumption And Popularity Of Offers In Junk food Companies." Economic Science For Rural Development Conference Proceedings 29.

Prachi Hajare Wani \& Nandkishor Sarode, Impact Of Junk food Consumption On Health, International Journal on Recent Trends in Business and Tourism, Vol. 2 (3) 2018.

Sriwati. (2000). Perlindungan Hukum Bagi Para Pihak Dalam Perjanjian Baku. Jurnal Yustika: Media Hukum Dan Keadilan, 3(2).

Kitab Undang-Undang Hukum Perdata

Undang-Undang Nomor 8 Tahun 1999 Tentang Perlindungan Konsumen 